\title{
PLACE NAMES ABOUT LIFE BY THE SEA - AN ARCHAEOLOGICAL PERSPECTIVE ON THE ESTONIAN-SWEDISH LANDSCAPE
}

\author{
Kristin Ilves
}

\begin{abstract}
No toponym has come from nothing and there has always been a link between a place and its name. When it concerns the past, it is a scholar's task to explore this connection. The article discusses Estonian-Swedish maritime place names from an archaeological perspective, and is based on the premise that research into toponyms should depart from the principle that the scholar tries to reconstruct the name giver's viewpoint. The article deals with two main topics: the meanings of place names related to the Estonian Swedes' possible practical use of the coast and sea, and, more importantly, to the possible function of place names as indicators of archaeologically interesting maritime locations. Also, the question of the dating of place names will be touched upon. The perspectives of different place names as indicators for locating landing sites will be analysed at length.
\end{abstract}

Key words: archaeology, Estonian Swedes in Noarootsi/Nuckö, landing sites, maritime place names, toponymy.

\section{INTRODUCTION}

It is relatively tempting to assume that every place in a landscape has a name or, at least, has had one. But the truth is that this is not and has not always been the case. For example, not every hill depicted on the surprisingly accurate 17th-century village maps has a designation, in the same way that not every field has a name known by the people inhabiting my home village today. Similarly to various habitation territories, and mainly in conformity with the situation of subsistence and economy in the area, but possibly also owing to other, cognitive factors, which may have had a role in the choice of settlement area (see further Lang 1999, Vedru 2002), people have named places departing from the same principle throughout the history of mankind. Only the locations important to men have been given names to distinguish these from places that lack significance for them. To a certain extent the naming has been regulated by livelihood, since, for example, only these capes, bays, stones and shallows which have been significant from the viewpoint of navigation and fishing have 
been given names, while all other similar objects in the same milieu have remained without any designation. Their relevance and being a part of mankind's life and economy has been the main part in the naming process (Pall 1997: 19, Kallasmaa 2000: 112-113). This is the reason why place names known and used by fishermen differ from those that are used by farmers, even if both fishermen and farmers lived in the same village (see Pitkänen 1998).

All place names are culture-dependent and convey a meaning - nomen est omen -, content that unfortunately often vanished in the course of time after a place lost its importance. But no place name has come from nothing and there has always been a connection between a place and its name. When it concerns the past, it is a scholar's task to explore this connection.

The paper discusses Estonian-Swedish maritime toponyms from the Noarootsi/Nuckö ${ }^{1}$ district in Estonia. The author of the article does not seek to present profound original linguistic argumentation, owing to the lack of competence in this area, and relies on works by other authors. The central issues in the article are: the meanings of place names related to the Estonian Swedes' possible practical use of the coast and sea, and, more importantly, to the possible function of place names as indicators of archaeologically interesting maritime locations.

\section{ESTONIAN SWEDES - THEIR TERRITORIES AND PLACE NAMES}

Before the Second World War and the years 1940-1944, there was a Swedish population in Estonia. Precisely when and from where Swedes came to Estonia is still under discussion. The first written reference to a Swedish presence is made in the Haapsalu/Hapsal Town Charter from 1294, where Swedes are mentioned as settled in the town of Haapsalu and other territories (LUB III 1857). The latest archaeological research carried out by Felicia Markus in the village of Einbi/Enby on the Noarootsi peninsula suggests that Swedes could have arrived at this area already in the early Iron Age (Markus 2004) instead of the more widespread statement of their arrival and continuous settling in the 13th century and later (Johansen 1951, Blumfeldt 1961, Jakobsson 1980, etc). In my opinion, data, although sparse as yet, but made up of both tangible and intangible cultural elements, support the argument that the first Swedes on the Noarootsi territory are known to have settled since the end of the Viking Age at the earliest. Also, as has been strongly emphasised by Markus, more archaeological fieldwork in these territories is urgently needed, since 
field studies have been rarely conducted in the Noarootsi district and this fact seems to have been generally overlooked (as, for example, in Mandel 2003). Thus, it has been virtually impossible to associate the few traces of possible prehistoric human activity known so far with ethnicity and, also, all dating is unfortunately still hypothetical.

The Swedish settlement was spread over quite a large area along the Estonian north-western coast and on the islands north and west from the mainland, while the core of the Swedish areas was the districts of Noarootsi and Vormsi/Ormsö in the north-western corner of the Estonian mainland, south from the mouth of the Gulf of Finland (Tammekann 1961: 11). The Vormsi district is comprised of the island by the same name. Also, the Noarootsi district is, quite similarly to the island of Vormsi, geographically well delimited - open sea to the north and west, the long bay of Haapsalu on the southern side and big marshy areas bordering it on the eastern side.

The parish consists of Noarootsi peninsula and, opposite it, separated by some shallow terminal lakes, a mainland strip in the east and northeast up to Põõsaspea/Spithamn cape. The parish includes some islands as well, Osmussaar/Odensholm being the biggest of these. At present, the Noarootsi district with the total area of $296 \mathrm{sq} \mathrm{km}$ has a coastline of ca $100 \mathrm{~km}$. In former times, the length of the coastline was considerably longer since the Noarootsi peninsula was a landscape of islands - shallow straits still separating Noarootsi peninsula from the mainland can be seen even as late as in the 18th-19th century (see, for example, Mellin 1798).

Place names in the former Estonian Swedes habitation areas, in the northwestern part of Estonia, have been systematically and purposefully collected and studied already before the Second World War. With the impending threat of the Soviet occupation in the 1940s, Swedish scholars started to systematically and urgently document the soon-to-be-vanished language of the Estonian Swedes. But since the Estonian Swedes had always been a minority group with a special status in Estonia, their history and language was under principal academic interest already before. In addition, several collections were published, making the source material easily accessible. One of the earliest works on the Estonian-Swedish population and place names that also includes place names in Noarootsi parish, is from 1855: Carl Russwurm's Eibofolke oder die Schweden an den Küsten Estlands und auf Runö. Paul Johansen's work on the history of Estonian Swedes is remarkable, and he also discusses place names at length in his book Nordische mission, Revals Gründung und die Schwedensiedlung in Estland (1951). Also, Edvin Lagman has dealt with Estonian-Swedish language, dialects, and place names and his work is published in the book En bok om Estlands svenskar 2 (1964). Specifically for the Noarootsi area, the language of 
this territory, including place names, has been published in the dictionaries Ordbok over Nuckömålet by Gideon Danell (1951), and Supplement till G. Danells Ordbok over Nuckömålet by Fridolf Isberg (1970), the latter being the most comprehensive collection of published place names about the Noarootsi district. This article is based on the study drawing on all these sources on different kinds of topographical place names.

In all the mentioned sources, a thorough linguistic analysis of place names has been provided, largely owing to the situation that research in onomastics has long been focussed on the study of place names as a part of the linguistic environment rather than something else. Therefore, unfortunately, from an archaeological perspective it is important to note that even though the origin and composition of names is to a certain extent clarified, names in collections are mostly presented in association with the village units and are not precisely geographically positioned. Toponymical information is thus not easily to locate. Moreover it is also important to remember that names may move, and their types differ. Names can be borrowed, changed, forgotten, and replaced. They may often change the target (see for example Slotte 1988, Ainiala 1997). The collected toponymical data used in this article date back mainly to the 19th and the beginning of the 20th century. Could we ever reach beyond speculations about the background of one or another name by studying place names collected in the 19th-20th century? Is it possible to extrapolate these to the past in order to obtain archaeologically and historically relevant information?

Through the impact of memories, legends and given names, childhood ideals, value judgments, but also lights, shadows and smells, various activities, etc, which are connected with different places, mankind attaches a meaning to its surroundings. The cultural landscape is being created. And it is being inherited to the following generations, who fill it with its own meaning and values. The layers of landscapes from different eras grow on one another. But as long there are "stories" about the surrounding landscape, it is a living landscape and we can reconstruct older phases (Palang 2001: 9). Place names constitute a powerful "story" about cultural landscapes. And these are shown to be relatively stable despite all the possible reservations mentioned above. Estonian archaeologist Heiki Valk (2006) has even deducted on the basis of many traditions originating in the preliterate society which was preserved in the Estonian countryside up to the 19th and early 20th century that various expressions of oral culture lasted longer in Estonia in comparison with Scandinavia or West-European countries. Place names are seldom deliberately changed (still, it has happened for nationalistic purposes) and village names in the Noarootsi parish have been documented already since the 14 th -15 th century, which is a remarkable evidence of their stability. Nevertheless, there is a rather great and serious threat of 
misreading and misusing the toponyms in collections. This is why it is important to use older cartographic material when working with place names from the archaeological/ historical viewpoint, in order to minimize the impact of earlier conclusions and possible errors - in the case of Noarootsi, the oldest maps are from the 17th century, but the most useful maps have turned out to be from the 18th-19th century. In addition, field studies on the actual landscape are required.

\section{MARITIME PLACE NAMES}

On the basis of the books about Estonian-Swedish place names, it seems to be only natural to draw the conclusion that the overwhelming majority of place names in the Noarootsi district might be called agrarian. There are general names which designate meadows, pasturages and fields. However, a more thorough analysis reveals that the systematisation of the place names (on the basis of denotation) can be totally misleading for a researcher and lead to grave misinterpretations about the meaning of the names. To exemplify it more specifically, the meaning of place names has frequently changed throughout time: Präst-viken (priest bay) in Einbi is an example of a displaced name - from a bay that has dried up to grazing ground. In the case of the village names Skatenäs (topmost cape), Gutanäs (fish-fry cape), Kolnäs (coal cape) and Bysholm (village islet) it is possible to observe how names marking a cape or an islet have become to mark a village. On that account, research into toponyms should depart from the principle that the scholar tries to reconstruct the name giver's viewpoint: what the name giver was trying to convey with a place name. The meaning a name has been assigned in the course of time is not so important in the present connection.

Still, the overwhelming majority of place names collected in the Noarootsi district are agrarian (such as Kvarn-backen [windmill hill], Gärde-backen [fenced field hill], Betan [pasture], Havre-horvan [little fenced field of oak], Far-åkrarna [sheep fields], etc.), but a considerable number of the names are also maritime. "Maritime" refers to place names which mark something in the maritime milieu (e.g. islets, islands, shallows, shoals, reefs, coasts, bays, etc.) and which according to interpretations have marked or indicated places connected with the maritime sphere (among others, landing places, harbours, fishing sites, wrecking sites, shipping lanes, etc).

A number of maritime place names that mark maritime locations in the Noarootsi district are positional - i.e., they are related to the position of a place, as Näs-udden (cape on a foreland), Pasklep-viken (bay by Paslepa/Pasklep 
[village]), Örjans-grunds-leden (sea-lane by Örjan's [a person's name] shallow). Another method has been to stress to whom a spot belongs, even in the maritime milieu: Simons ören (Simon's [personal name] gravely ridge), Smedens ören (blacksmith's gravely ridge), Hargabo-näs (Hara/Harga villagers cape), Udenküll holmen (Uugla/Udenküll [manor's] islet). A similarity in form has often inspired the name givers and so, in the Noarootsi district there are, for example, stones in the sea near Riguldi/Rickul that have been named as Hunden med ungarna (a dog with puppies) and Säl-huvudet (seal's head). In the waters near a small settlement of Pai/Paj there is a stone which carried a bizarre name - Långåker-flutan (long field [-shaped] water plane close stone). Also, a somewhat special characteristic of the site may have been a source for inspiration: Gräsören (grassy gravely ridge) on the coast of Einbi village marked probably a gravely ridge covered with somewhat more grass than other gravely ridges on the nearby coasts at the time of name giving; Röd-stenen (red stone) in Österbi/ Österby marked a stone that was red in colour, etc.

The name of the whole district under discussion - Noarootsi/Nuckö - which derives from the present-day peninsula, but in earlier times marked an island by the same name, is, similarly to the latest example, also given according to a special characteristic of this geographical unit. The Estonian-Swedish name Nuckö is linguistically interpreted as an island with a (prominent) cape. Once the island of Noarootsi had many capes, but as the name contains the genitive singular form of the word nuka (point/tip? cape) (Lagman 1964: 17), it is probably one particular cape that is referred to. As there have been several remarkable capes in the region, it is difficult, in my opinion, at the present state of research to argue for one or another, mainly because owing to insufficient archaeological fieldwork we do not yet know about the objective background of the name, i.e., how the settlement was organised, etc. But, while sailing the waters surrounding the island of Noarootsi in the past, several prominent forelands caught the eye and this sight seen from the sea must have been significant for the origin of the name - we should consider the possibility that the name givers had come from the sea. It is plausible that the seafarers' viewpoint was not motive for the naming system, but it could have played a major part in its development and stabilisation (Gelling \& Cole 2000: xvi; see also Brink 1981). As to Noarootsi, the view, seen from boats/ships sailing the nearby waters, must have influenced the eventual selection of a topographically prominent and characteristic feature - the cape - to refer to in the name of the whole island.

However, the function of place names is not usually connected with the task of describing the landscape, because there is no need to describe the landscape for those who live in it. For people who gave and used place names, these were primarily a means of communication for navigating in the landscape 
and using it. Toponyms often reflect the possible cause of their origin and often we find information about the relation between people and locations. On several occasions, name givers have also provided information about the inhabitants' maritime use of places. Names of this type reflect a site's function and let us know among other things about the means of subsistence of the Noarootsi inhabitants. Names such as Aborr-grunden (perch shallow), Strömming ören (dwarf herring ridge), Strömmings mynnet (dwarf herring estuary), Sill-grundet (herring shallow), Gäddans skaten (pike cape), Gös-stenen (pike stone) and Bytesnät-stenen (catch net stone) definitely tell us about the inhabitants' fishing activities and about their catch in different locations. It is historically known that dwarf herring, herring and pike have given the best and lasting catches to Estonian Swedes (Stahl 1964). Information about the Noarootsi inhabitants' relation to seabirds and to the places where they reportedly carried out fowling or gathered eggs or feathers is given in names such as Gås-stenarna (goose stones), Gås-örarna (goose ridges), Höns-grundet (hen shallow), and Skarvskaten (cormorant cape). There are also place-names like Skytt-grundet (hunter shallow), Skytt-stenen (hunter stone), Säl-viken (seal bay), Säla-grund (seal shallow), Säl-krokarna (seal hooks), which in maritime culturescape is associated with hunting. Even though seal hunting has primarily been associated with the Ruhnu/Runö islanders (Stahl 1964: 229), seal hunting was also among the main activities of the people of Noarootsi.

Several names are connected to places that have been important from the viewpoint of seafaring and navigation. Vänd-grund ([take a] turn shallow) and Vänd-grund-stenen ([take a] turn shallow's stone) in the Sutlepa/Sutlep sea, convey a clear meaning of taking a manoeuvre and instructing that it is here that one must change the course. The names Lägga-stenarna (place stones) and Rep-stenen (rope stone) suggest that these stones could have functioned as anchoring points. The name of Kors-backen (cross hill), marking a prominent hillock on the coast by Spithami/Spithamn village at the old sea-lane, can be interpreted as a seamark name. The fact is that this hillock stands on its own and is conspicuous, especially if viewed from the sea, and was probably used to facilitate navigation. Very likely, the shallows Stapel-bottnen (pole bottom) and Stor-stapeln (big pole) were also important for navigation. Another important activity for local seafarers everywhere in the Baltic Sea region was to mark out hazardous underwater shallows with poles (see, for example, Andersson 2003). Skepps-stenen (ship's stone) and Skeppar grundet (skipper's shallow) tell that there may have been a shelter for ships near these locations or a site of a shipwreck nearby; it is also possible that a seaman lost his life near the named location and this was the reason for the emergence of such a name. It is a wellknown fact that locations were given names owing to some unusual and memor- 
able event (Hiiemäe 2001: 91). For example, Kaparev (privateer reef) by Osmussaar bears witness to an accident on the sea or, according to Albert Engström (1976: 202-203), this name tells about robbing and plundering attempts in late medieval times. Exceptional names such as Kogg-sten (cog stone) and Koggnäs (cog cape), also Kogg-hamn (cog harbour) and Kogg-krog (cog tavern) near Österbi outline that cogs, the relatively large and deep sailing crafts from the early medieval times, have stood in the harbour or been grounded near these places.

\section{DATING PLACE NAMES}

The complex of local place names always represents a kind of linguistic mapping of geographical surroundings, done by the locals throughout history - and it has always much to tell about the people who gave these names, and how they understood reality around them. But as Kurt Zilliacus has pointed out in his name theory (2002), almost all names are multilayered and the results of analysis of toponyms remain hypothetical if these are not supported by practical and structured facts. From the archaeological perspective, the age of names is certainly the most important aspect of a place name to become "useful". In case of the cog names, we get information about the approximate age of the places, but predominantly the name itself does not hold any about the age. Still, land mass uplift in the coastal areas provides a special field for the investigation of localities marked with place names of interest. The elevation outlined on the topographical maps is often helpful in determining the name's approximate age and its tentatively designated object on the landscape.

The modern Noarootsi district used to be an extensive landscape of islands, which has by now vanished as the whole Baltic Sea region is influenced by the land uplift. This elevation differs significantly from region to region, but in Estonia it is fastest in the area of the Noarootsi district. The area's rate of shore displacement has been calculated to $2.8 \mathrm{~mm}$ per year on the peninsula and 2.9-3.1 $\mathrm{mm}$ per year on the northern mainland territories (Nõulik 2001: 39-40, Hoppe et al. 2002). Bearing in mind that natural objects do not have a clear borderline and are extremely temporal, the general calculations on the former location of coastline in the Noarootsi area have been made: +1 m isobase of land uplift is considered to represent the coastline as it was in $1650 \mathrm{AD}$, the $+2 \mathrm{~m}$ curve shows the coastline in $1290 \mathrm{AD}$, and the +3 m curve roughly marks the coastline in $940 \mathrm{AD}$. Nevertheless, the process of land mass uplift is not linear but has varied in the course of years - thus, the values presented here should be looked upon as approximate and not as absolute values. 
After reconstructing the area on the basis of shore displacement calculations, we can see considerable difference in the seafront and expanse nowadays - ca 1,000 years ago, by the end of the Viking Age, Noarootsi peninsula was just an island of $32.6 \mathrm{sq} . \mathrm{km}$, begirded with some tiny islets, and the coastline of mainland territories was much more indented than it is today. It was a real islescape and, remarkably, in the first written sources mentioning Estonian Swedes and their territories, the so-called mainland localities of the Noarootsi parish were referred to by the name dat Eyland (1391), insulas Elandt (1449), Eylandth (1536) (Johansen 1951: 236). Amongst the linguistic interpretations of this name, which include, for example, "the low coastal area" (Lagman 1964: 19), there is also an explanation of the name "the land of islands" or "the land in the vicinity of islands".

\section{PLACE NAMES AND MARITIME ARCHAEOLOGY}

In prehistory (and in some places even up to our day), waterways were vital means for maintenance, communication and trade. Clearly, travel by water depends on water vessels, but at the same time it analogously depends on places for landing - namely, on passage points between land and water. Thus, there have probably been many different places for landing with many different functions. Perhaps encouraged by this possibly high number, landing sites have been for land-based archaeology around the Baltic Sea one of the most interesting prehistoric research objects in the maritime cultural landscape for the last 30 years (see for example Lundström 1971, 1973, 1981, Cederlund 1980, Crumlin-Pedersen 1985, Carlsson 1987, 1991, 1998, Herrmann 1988, 1995, Näsman 1991, Ulriksen 1998, Dobat 2002a, Bogucki 2004, Mägi 2004).

Unfortunately, most landing sites, like many other sites in archaeology, are relatively invisible. Thus - as a solution - in locating the places for landing, looking at their context, such as the prehistoric landscape, has been given a high priority. Quite a lot different analysis- and prospecting methods have been applied in this work (see, for example, Westerdahl 1989), while this article will be restricted to place names that are often among the most important tools for locating the sites for landing. To stress the role of place names in the archaeological study, and, most of all, showing their significance as indicators for archaeological sites on former coasts, is as yet uncommon in Estonian maritime archaeology. At the same time, the use of place names as indicators is a widely used practice, for example, in Scandinavia (see, e.g., Olsson 1972, Westerdahl 1989, 1991, Dobat 2002b). 
In a careful investigation of place names one primarily tries to establish what name givers had intended to convey with a name, one endeavours to depart from the name givers' point of view, their possible situation in life, their worldview and the purpose of the name. Interpretations of names are connected with the meaning what name givers had in mind, and not with other associations that have been tied to the names afterwards (Zilliacus 2002: 43). Quite a large number of place names in the Noarootsi district have a clear maritime meaning but by the time of collecting, these already marked places in landscape with no maritime significance (such as arable lands, grazing grounds, meadows, swamps, ditches, hills). In terms of the unambiguous names such as Sand-hamnen (sand harbour, i.e. a harbour with a terrain sandier than others) in Rooslepa/Roslep and Lill-hamnen (little harbour) on Osmussaar, which both marked pastures by the time the place names were collected and recorded, there is probably no doubt that these place names used to mark harbour sites. In the course of time, the harbour sites dried up and became to be used as grazing grounds, but the harbour names survived and their designation altered. Likewise, the name Gamlas-å-hamnen (old river harbour, i.e., harbour by an Old River, or harbour by a river that is old), which stands for a dried-up river bed in Spithami, had some time during history marked a landing site for boats. Although cartographic research helps to determine the time at which there may have been landing place near the mentioned sites, there is still a need for archaeological fieldwork to firmly establish these location of these landing sites. In the case of Gamlasa-hamnen in Spithami, the site was located during an archaeological field survey in autumn 2005; an even thick cultural layer was detected nearby, but the exact dating of it will remain for the future.

Besides the names discussed above, which have probably first marked landing sites and only then their meaning changed, there are place names in the Noarootsi district which are indicative of places for landing. Such are the maritime place names that have been interpreted as marking localities close to landing sites. For example, the place names which are categorised among the place names that mark pasturages Hamn-sten-viken (harbour stone bay, i.e. a bay with a prominent stone close to the nearby harbour) in Paslepa or Hamn-bäcken (harbour stream, i.e. a stream by the harbour) on Osmussaar. Also, field names Hamn-gården (harbour homestead, i.e. a farm by the harbour) in Rooslepa and Hamn-horvan (harbour field, i.e. a little fenced field by the harbour) in Luksi/Lukslaggen. As indicating place names that quite plausibly refer to localities related to the sea it is possible to mention Nät-holms-backan (net islet's hill) - the name which marked a field in Hosbi/Hosby and a pasturage in Sutlepa, Not-gist-horvan (net shed field) and Näte-klippan (net rock) - the names marking field and grazing ground in Kudani/Gutanäs, respectively. The 
relation of these localities to the sea and the connection to seafaring and fishing is also conveyed by place-names Ankar-mossen (anchor marsh) in Rooslepa and Fisk-kull (fish hill) in Riguldi.

Quite often the place names possess a notable character and thus mark localities that lack other evidence of a possible maritime connection. In the case of the geographically oriented cultural historical research in archaeology it is important to survey all these localities to explore the significance of a place name. Except the places on the island of Osmussaar, all other localities with indicative names are nowadays quite a long way inland. Landscape reconstruction has already shown that several spots were located near the coast during the late Viking Age and early medieval times, i.e. during the times of possible Swedish occupation. With archaeological methods we could both prove and explain the places' and peoples' relation to the sea, without which we will always stay on a hypothetical level. At the same time, we should remember in our interpretations that names to places were given not for explaining the reasons for naming but to fulfil important tasks in the linguistic communication of the inhabitants (Zilliacus 2002: 175-176) and this is a rather difficult realm to study and make convincing statements.

Besides place names which according to their interpretation directly mark or indicate coastal locations there is a group of place names, often used in maritime landscape archaeology, which are indeed clearly indicative and, in the general sense rather than specifically, related to the sea and seafaring. These are the so-called "chapel names".

There are known to have been three chapels in the Noarootsi district - in Rooslepa, Sutlepa and on the island of Osmussaar. All of these are also marked with some chapel names in the vicinity, as Kapell-backen (chapel hill), Kapellvägen (chapel road), Kapell-horvan (little fenced field by the chapel), etc. Curiously, there are also chapel names in the areas where no chapel is known to have existed. For example, Kapell-gärdan (fenced field by the chapel) and Kapell-skate (chapel cape) in Riguldi, Kapell-backen (chapel hill) in Paslepa, Kapell-horvan (little fenced field by the chapel) in Österbi or Kapell-gärdet (fenced field by the chapel) and Kapell-bron (chapel way) in Spithami, etc.

Finnish researcher of toponyms, Kaija Mallat has pointed out that different names can have different history and meaning despite their relatively comparable and similar form (1997). Analogously to the example of Kirkkomäki (church hill) used by Mallat we could explain one of the most popular chapel name Kapell-backen (chapel hill) in one of the following ways: * one can see a chapel from this hill, * once, a chapel stood on this hill, * a chapel was planned on this hill, * the hill is as big as a chapel, * divine services or other similar rituals were carried out on this hill (i.e. the hill was used as a chapel), 
* timber was felled or stone brought from this hill to build a chapel, * the hill was on a way to a chapel, * people made a stop by this hill on their way to a chapel. Therefore, the name Kapell-backen (chapel hill) may also indicate a site by the chapel or a chapel near this place, or the usage of the place as a chapel and the measurements and form (heights) of the place. Also, other interpretations are possible. On that account, it is extremely important to study the milieu of a name and its origin in the local context.

In Estonian archaeology, chapel names have had quite an important role in positioning prehistoric monuments. Namely, it has proved helpful in locating burial places of different age. In the Noarootsi district, too, there is an old graveyard registered in a place called Kapell-backen (chapel hill) in Aulepa/ Dirslätt. There are also legends about a cemetery in a place called Kapellgärdan (fenced field by the chapel) in Riguldi. Research done in Scandinavia (Ulriksen 1998, Dobat 2002a, etc.), however, has furthermore referred to that Romanesque churches on the coasts could be considered a criterion for locating bigger prehistoric and early medieval landing sites. Likewise, chapels which have been close to coasts on several occasions marked places for landing or even harbours (see, for example, Cederlund 1980, Baudou 1988, Norman 1991, Pao 2004). For this reason, it is appropriate to use chapel names as important information for research aimed at locating landing places even in Estonia. Especially since such names can be encountered in the Noarootsi district almost without exceptions near the former coastline, marking the peripheral areas of land uplift.

\section{CONCLUSION}

Proceeding from the discussed toponymical material from the Noarootsi district there come forth several locations in the landscape which have a high potential for locating former coastal localities which had belonged to the earliest settlers; especially if other cultural and also topographical particulars that are important in landscape prospecting, concentrating on the possible maritime use of places, are added. A relatively strong concentration of indicators for finding early landing sites near the probably oldest villages in the Noarootsi district - Paslepa, Sutlepa and Rooslepa (Johansen 1951: 124, 246, Lagman 1964: 57) - could on the occasion of their successful localisation (if one dares to speculate boldly) even date the first settlement of Swedes in these territories.

Throughout the history of Estonian Swedes in Estonia, their position by the sea has had considerable significance for their lives - for them fishing, seal hunting, seafaring and also smuggling, side by side with agriculture, were 
essential aspects in subsistence. But the continuous land mass uplift and its effect on the functioning of maritime economy was fairly negative. The fishing waters and fish disappeared, landing sites needed to be moved and new sea lanes created. But the remains of the old constructions are left on the landscape, among other things in form of place names. Much information about the early maritime use of spaces by the settlers can be reconstructed from the toponymical material of the Noarootsi area. Moreover, it is possible to get indicative information about the prehistoric coastal locations. Owing to the possibility of dating place names on the basis of shore displacement calculations the names' meaning can be explicated. Of course, one should always remain strongly critical to the information retrieved from place names and use it very cautiously, but still, archaeologists should always reckon with place names as a supplementary source and observe this data before fieldwork. Field studies are important to test the value of information about place names for archaeological research.

\section{Acknowledgements}

This article was written in the framework of the project "Coastal Settlements on Prehistoric and Medieval Saaremaa" financed by the Estonian Science Foundation (Grant no. 5432).

\section{Comments}

1 Since parallel (partly official) Estonian and Swedish names are in use in the Noarootsi/Nuckö district for larger administrative units, both forms are given at first mention, while the Estonian variant will be preferred further in this article.

\section{References}

Ainiala, Terhi 1997. On perpetuation, demise and change in place names. In Ritva Liisa Pitkänen \& Kaija Mallat (Eds.). You name it. Perspectives on onomastic research. Studia Fennica Linguistica 7. Finnish Literature Society. Helsinki, pp. 106-115.

Andersson, Jan 2003. Rödhamns värld. Historien om livet vid Åland stora farled. Ålands landskapsstyrelse, Museibyrån.

Baudou, Evert 1988. Det maritima kulturlandskapet och den arkeologiska forskningen i Norrland. In Lars Holstein (ed.). Det maritima kulturlandskapet kring Bottenviken. Artiklar och studier från Bottenviksprojektet. Umeå, pp. 168-179.

Blumfeldt, Evald 1961. Estlandssvenskarnas historia. In Edvin Lagman (ed.). En bok om Estlands svenskar 1. Svenska Odlingens Vänner. Stockholm, pp. 63-178.

Bogucki, Mateusz 2004. Viking Age ports of trade in Poland. Estonian Journal of Archaeology, 8: 2, pp. 100-127. 
Brink, Stefan 1981. Namnet Hälsningland. Namn och bygd, 69, pp. 115-151.

Carlsson, Dan 1987. Äldre hamnar - ett hotat kulturarv. Fornvännen. Årg 82, pp. 6-17.

Carlsson, Dan 1991. Harbours and trading places on Gotland AD 600-1000. In Ole Crumlin-Pedersen (ed.). Aspects of Maritime Scandinavia AD 200-1200. Proceedings of the Nordic Seminar on Maritime Aspects of Archaeology, Roskilde, 13-15 March, 1989. Vikingeskibshallen i Roskilde, pp. 145-158.

Carlsson, Dan 1998. Vikingahamnar. Ett hotat kulturarv. ArkeoDok 1. Visby.

Cederlund, Carl Olof 1980. Marknadshamn, gårdshamn, fiskehamn eller övernattningshamn? Människan, kulturlandskapet och framtiden. Föredrag och diskussioner vid Vitterhetsakademiens konferens 12-14 februari 1979. Konferenser 4. Kungl. Vitterhets Historie och Antikvitets Akademien. Stockholm, pp. 176-184.

Crumlin-Pedersen, Ole 1985. Havne og søfart i romersk og germansk jernalder. Henrik Thrane (ed.). Gudme problemer. Beretning fra et bebyggelsearkæologisk symposium på Hollufgård afholdt den 24.-25. oktober 1984. Skrifter fra historisk institut, Odense Universitet, nr 33. Odense, pp. 68-91.

Danell, Gideon 1951. Ordbok över Nuckömålet. Lund.

Dobat, Andres Siegfried 2002a. Die Schlei in der Wikingerzeit. Eine Maritime Kulturlandschaft im Spiegel der archäologischen und onomastischen Quellen. Schriftliche Hausarbeit zur Erlangung des Grades eines Diplom-Prähistorikers (Dipl.-Prähist.) der Mathematisch-Naturwissenschaftlichen Fakultät der Christian-Albrechts-Universität zu Kiel. Kiel.

Dobat, Andres Siegfried 2002b. Snekke-Namen an der Schlei. Zeugnisse einer Maritimen Infrastruktur im Umfeld von Haithabu und Schleswig? Archäologisches Korrespondenzblatt, 32, Heft 4, pp. 607-620.

Engström, Albert 1976. Mitt liv och leverne. Stockholm.

Gelling, Margaret \& Cole, Ann 2000. The Landscape of Place-names. Shaun Tyas, Stamford.

Herrmann, Joachim 1988. Zur Struktur von Handel und Handelsplätzen im südwestlichen Ostseegebiet vom 8.-10. Jahrhundert. Bericht der Römisch-Germanischen Kommission. Band 69, pp. 720-739.

Herrmann, Joachim 1995. Frühe Seehandelsplätzen am „äußersten Ende des westlichen Ozeans”. Geschichtliche Grundlagen, siedlungstopographische Strukturen und ethnische Herkunst ihrer Bewohner. Acta Praehistorica et Archaeologica, 26/27, pp. 5772 .

Hiiemäe, Mall 2001. Maastik ja kohapärimus. Hannes Palang \& Helen Sooväli (eds.). Maastik: loodus ja kultuur. Maastikukäsitlusi Eestis. Tartu, pp. 86-95.

Hoppe, Göran, Nõulik, Ingrid \& Punning, Jaan-Mati 2002. Shoreline development and Swedish colonisation of north-west Estonia during the Middle Ages. GeoJournal, 56, pp. $185-190$.

Isberg, Fridolf 1970. Supplement till G.Danells Ordbok over Nuckömålet, 1-2. Uppsala.

Jakobsson, Svante 1980. Osilia-Maritima 1227-1346. Studier kring tillkomsten av svenska bosättningar $i$ Balticum, i synnerhet inom biskopsstiftet Ösel-Wiek. Studia Historica Upsaliensia 112, Uppsala, Stockholm. 
Johansen, Paul 1951. Nordische Mission. Revals Gründung und die Schwedensiedlung in Estland. Kungl. Vitterhets Historie och Antikvitets Akademiens Handlingar, del 74. Stockholm.

Kallasmaa, Marja 2000. Koht, nimi ja kohanimi / Places, Names and Place Names. Kaia Lehari \& Virve Sarapik (eds.). Koht ja paik / Place and Location I. Proceedings of the Estonian Academy of Arts 8. Tallinn, pp. 112-128.

Lagman, Edvin 1964. Ortnamn och terrängord i Estlands svenskbygd. Edvin Lagman (ed.). En bok om Estlands svenskar 2. Svenska Odlingens Vänner. Stockholm, pp. $7-125$.

Lang, Valter 1999. Kultuurmaastikku luues. Essee maastiku religioossest ja sümboliseeritud korraldusest. Eesti Arheoloogia Ajakiri, 3: 1, pp. 63-85.

LUB III = Liv-, Esth - und Curländisches Urkundenbuch nebst Regesten. Hersg. F. G. v Bunge. Bd 3. Reval 1857.

Lundström, Per 1971. Lagunhamnarnas tid. Sjøfartshistorisk Årbok 1970. Bergen, pp. 41-52.

Lundström, Per 1973. S:t Olofs hamn på Drakön. Sjöhistorisk Årsbok. Föreningen Sveriges Sjöfartsmuseum i Stockholm, pp. 89-104.

Lundström, Per 1981. De kommo vida... Vikingars hamn vid Paviken på Gotland. Sjöhistoriska museets rapport. Stockholm.

Mandel, Mati 2003. Läänemaa 5.-13. sajandi kalmed. Eesti Ajaloomuuseum. Töid ajaloo alalt 5 . Tallinn.

Mallat, Kaija 1997. Interpreting place names. Ritva Liisa Pitkänen \& Kaija Mallat (Eds.). You name it. Perspectives on onomastic research. Studia Fennica Linguistica 7. Finnish Literature Society. Helsinki, pp. 97-105.

Markus, Felicia 2004. Living on Another Shore. Early Scandinavian Settlement on the North-Western Estonian Coast. Occasional Papers in Archaeology 36. Uppsala.

Mellin, Ludwig August 1798. Atlas von Liefland oder von den beyden Gouvernementern u. Herzogthümern Lief- und Ehstland und der Provinz Oesel. Riga; Leipzig, 1798. Nr. V. Der Hapsalsche Kreis.

Mägi, Marika 2004. “...Ships are their main strength.” Harbour sites, arable lands and chieftains on Saaremaa. Estonian Journal of Archaeology, 8: 2, pp. 128-162.

Norman, Peter 1991. Maritime monuments from the Viking period and early Middle Ages in the Kalmarsund area. Ole Crumlin-Pedersen (ed.). Aspects of Maritime Scandinavia AD 200-1200. Proceedings of the Nordic Seminar on Maritime Aspects of Archaeology, Roskilde, 13-15 March, 1989. Vikingeskibshallen i Roskilde, pp. 121-130.

Nõulik, Ingrid 2001. Noarootsi poolsaare looduse ja inimasustuse kujunemislugu viimase tuhande aasta jooksul. Magistritöö. Käsikiri Tallinna Ülikooli Akadeemilises raamatukogus.

Näsman, Ulf 1991. Sea trade during the Scandinavian Iron Age: its character, commodities, and routes. Ole Crumlin-Pedersen (ed.). Aspects of Maritime Scandinavia AD 200-1200. Proceedings of the Nordic Seminar on Maritime Aspects of Archaeology, Roskilde, 13-15 March, 1989. Vikingeskibshallen i Roskilde, pp. 23-40.

Olsson, Ingemar 1972. Snäck-namn på Gotland. Fornvännen. Årg 67, pp. 180-208.

Palang, Hannes 2001. Maastikest siin raamatus. Hannes Palang \& Helen Sooväli (eds.). Maastik: loodus ja kultuur. Maastikukäsitlusi Eestis. Tartu, pp. 8-10. 
Pall, Valdek 1997. L'em't'ne. Eesti Keele Sihtasutus. Tallinn.

Pao, Bruno 2004. Sõrve sääre otsa lood. Saaremaa Merekultuuri Seltsi Toimetised. Kuressaare.

Pitkänen, Ritva Liisa 1998. The Nomenclatures of a Farmer and a Fisherman: Occupation as a Decisive Factor. Wilhelm Fritz Hermann Nicolaisen (ed.). Proceedings of the XIXth International Congress of Onomastic Sciences. Vol. 2. University of Aberdeen, pp. 277-284.

Russwurm, Carl 1855. Eibofolke oder die Schweden an der Küsten Estlands und auf Runö. Reval.

Slotte, Peter (Ed.) 1988. NORNA-rapporter 37. Denotationsbyte i ortnamn. Rapport från NORNA:s trettonde symposium i Tvärminne 9-11 oktober 1986. Uppsala.

Stahl, Andreas 1964. Sjöfart och fiske hos Estlands svenskar. Edvin Lagman (ed.). En bok om Estlands svenskar 2. Svenska Odlingens Vänner. Stockholm, pp. 191-230.

Tammekann, August 1961. Estlandssvenskarnas bosättningsområde. Edvin Lagman (ed.). En bok om Estlands svenskar 1. Svenska Odlingens Vänner. Stockholm, pp. 9-62.

Ulriksen, Jens 1998. Anløbspladser. Besejling og bebyggelse I Danmark mellem 200 og 1100 e.Kr. En studie af søfartens pladser på baggrund af undersøgelser $i$ Roskilde Fjord. Vikingeskibshallen i Roskilde.

Valk, Heiki 2006. Archaeology, Oral Tradition and Traditional Culture. Valter Lang \& Margot Laneman (eds.). Archaeological Research in Estonia 1865-2005. Tartu University Press, pp. 311-316.

Vedru, Gurly 2002. Maastik, aeg ja inimesed. Valter Lang (ed.). Keskus - tagamaa - ä̈rreala. Uurimusi asustushierarhia ja võimukeskuste kujunemisest Eestis. TallinnTartu, pp. 101-122.

Westerdahl, Christer 1989. Norrlandsleden I. Källor till det maritima kulturlandskapet. Härnösand.

Westerdahl, Christer 1991. Norrlandsleden: The maritime cultural landscape of the Norrland sailing route. Ole Crumlin-Pedersen (ed.). Aspects of Maritime Scandinavia AD 200-1200. Proceedings of the Nordic Seminar on Maritime Aspects of Archaeology, Roskilde, 13-15 March, 1989. Vikingeskibshallen i Roskilde, pp. 105-120.

Zilliacus, Kurt 2002. Forska i namn. Svenska litteratursällskapet i Finland. Helsingfors. 